\title{
Research on Teaching Management in Universities from the Perspective of Innovative Talents Cultivation
}

\author{
Li Hua \\ College of engineering and technology, Jilin Agricultural University, Changchun, 130118, China
}

\begin{abstract}
Keywords: Teaching management; Management education; Service
\end{abstract}
\begin{abstract}
The teaching management is the central work and plays a particularly important role in universities. It is the humanistic management work of teachers and students. Management and education is an important task of teaching management, and also an important part of the "three education" in universities. In addition, it plays an important role in the process of ideological and political education for college students. Universities also need to test in the market competition, and the innovation of teaching management methods in universities also has a vital role in improving the overall teaching quality of universities.
\end{abstract}

\section{Introduction}

Nowadays, the topic of global concern for higher education is to improve the quality of talents cultivation, which is the core task of universities which have task to popularize higher education. New Power of Higher Education and Research: Social Change and Development published by the World Higher Education Conference has pointed out: "The growing access to education is bound to challenge the quality of higher education, but to ensure the education quality is the priority among priorities in contemporary higher education development". To strengthen the quality of daily teaching management, focus on teaching reform and the results of the actual application, and to constantly improve the quality of personnel training, embody the value orientation of serving the growth of all students.

\section{Strengthening the Sense of Service}

With the growing popularization, diversification, the trend of socialization of higher education, the accompanying new changes and new requirements put forward a greater challenge for the teaching management staff. It requires them to have excellent business quality, to do a good job in management, and also to ensure the normal operation of teaching and make good coordination in all aspects. Teaching management work is complicated and trivial. As university teaching management workers, they should distinguish between primary and secondary based on the actual situation, make overall management, improve efficiency, adopt reasonable modern management tools and methods in work and make specific analysis, with flexible and not rigid methods. Due to the complication of teaching management work, modern management tools and methods should be adopted in the work, to ensure that all the information, notices, documents, etc. can be timely and accurately put in place, and the personnel shall have skilled operation of various office software and office equipment.

Various departments in universities should coordinate and communicate with other departments, in accordance with the "three education" of teaching education, service education and management education. As teaching management workers, they should have a strong sense of service and dedication, take serving teachers and students as their career pursuit, provide a comfortable environment for teaching, and play assisting role in the actual work. In the work, they should adhere to the people-oriented management concept, enhance service awareness, change the passive service to active service, establish a harmonious and happy working atmosphere and good interpersonal relationships, and also improve the efficiency. Management education, as the overall process, whole personnel and all-around moral education, is an important way for universities to strengthen and 
improve the ideological and political education of college students, and can promote the improvement of the education quality and the talents cultivation quality. Teaching management workers shall be conscientious, diligent and sincere with enthusiasm, effectively perform their duties in ordinary job, get the support and recognition of leaders and colleagues, and promote teaching management work to have breakthrough and innovation.

\section{Standardizing the Management System}

Universities shoulder the task of cultivating high-quality talents with innovative spirit and practical ability, to meet the requirements of the times and the needs of social development. It is necessary to deepen the reform and innovation of the teaching management system mechanism, and promote the teaching quality and teaching management level and the continuous improvement of the quality of personnel training, so as to complete the cultivation quality. Management education, is a process that the university functional management departments and their staff take education as the starting point and the end of the management work, and exert influence on the ideological and moral qualities as well as behavioral habits of subordinates, managers and other personnel through a series of purposeful, planned and organized management behaviors, to realize college education goals. Management education can promote the reform and development of higher education, and promote the formation of good university spirit and style of study. This requires the teaching management workers to establish a people-oriented management concept, and grasp the soul of management education. The process of university management is a process of educating people. It is necessary for the managers to improve the sense of responsibility, change the management concept, enhance the awareness of education and service concept, follow people-oriented concept, form human management system, and put forward concepts of benefit from management, efficiency from management and education from management.

Establishing and improving the teaching management rules and regulations is the basis for the management of education. Through the common requirements for everyone to comply with the rules of conduct or action guidelines, it is needed to form strict institutional management, create a good campus order and establish standardized work procedures. At the same time, it is needed to clarify the job responsibilities of teaching management, strengthen the management responsibility, give full play to the responsibilities of management and education, guide, coordinate and standardize the students, deepen the reform of the management system and form a new management mechanism with vitality and self-operation, to make the education management work more scientific. For this purpose, universities should enhance teachers' awareness of education, strengthen teaching management responsibilities, and promote the quality of talents cultivation. Adhering to the "combination of education and management" is to put the ideological and political education of students into the school management work. Teaching management workers should have the quality and ability to meet the needs of management work, continue to enhance themselves and realize the value of work, with the concept of service education at the same time.

\section{Innovating Work Methods}

The core of higher education teaching management is to ensure the normal teaching order. Teaching management is the focus of university education management in which the managers promote teaching activities to achieve the stated objective of the university through certain management tools and methods. The concept of "innovation" can be understood as updating the concept, to create new things from the spiritual and material aspects, change the unreasonable workmanship and working methods in practical work, guide recognition on the basis of practice, and reform the unreasonable and outdated ways of working in the teaching management. In teaching management, innovation is everywhere at any time. Each process in teaching management development needs innovation.

Achieving innovation requires cultivating innovative environments and soils. Teaching management team construction has not gotten rid of the rigid model. The traditional teaching 
management sometimes restricts the development of teachers and students, and too single and mandatory management model restricts the innovation and personality play, which are far away from the requirements to cultivate high-quality creative talents. Teaching management workers accumulate new knowledge in the repeated practice, get access to new information, get new ideas, and sum up new experience. In addition, they should innovate the teaching management methods. At the same time, they should conduct all teaching management work with the eye of development. Besides, the author believes that the powers shall be divided in the university and school (department), and it is needed to take the school (department) as the management body and expand the management authority and responsibility of school level. Moderate decentralization is conducive to the development of grassroots teaching units to enhance the vitality of development, and improve the enthusiasm of the work. In addition, it is also more suitable for the actual situation of teaching work, which avoids the situation that the central departments prevent the effective development of teaching management due to lack of grassroots practical experience.

The teaching management workers in universities should strengthen the teaching management, ensure the normal order, have the job consciousness, the sense of responsibility, have the talents and ability to adapt to the management, and be equipped with management ability, as well as capacity, theories and academic level corresponding to the job.

\section{Enhancing the Job Ability}

Teaching management work is the university's regular central work, and occupies a particularly important position in universities. With the function of taking service education, it is also the most humane management work. Teaching management is basic work with a set of management and service, and is the basis to ensure the order of teaching and improve the teaching quality. The nature of teaching management determines that the teaching management workers must have a certain professional quality and management skills. Teaching management work is complicated and trivial, and is mostly daily specific work, which requires the teaching management workers to do job diligently and carefully, have enthusiasm in education and dedication spirit in practical work, convey positive and positive energy, establish a teaching-oriented concept, serve the teachers and students wholeheartedly and complete the work satisfactorily with a high degree of responsibility.

Education management workers should also have a high human quality, and pay much attention to the managers' demonstration effect. If the ruler acts properly, the common people will obey him without being ordered to. In the education management work, the workers should, with a high sense of responsibility and dedication, constantly improve their level of knowledge and professional skills in practice, show good political quality and professional ethics, play a subtle role as model for the students, establish the correct three values, take the whole picture as the most important, and earnestly perform their duties by setting themselves as example to others.

The teaching management workers, who have a solid ability to apply information technology, can not only save a lot of time, manpower and material resources, but also improve the work efficiency. Only with skill in modern equipment, can they quickly and accurately handle a variety of teaching information and teaching data, and continuously improve the efficiency and quality. Teaching management workers can only ensure the normal operation of teaching, and complete the various tasks of the university with high-quality and high-efficiency, by equipping with various management tools for reasonable organization, guidance and scheduling. As teaching management workers, they should be innovative, with pioneering and innovative ability and awareness, conduct all teaching management work with the eye of development, carefully analyze existing problems and solutions and make efforts to cultivate talents meeting the development of the times.

\section{Conclusion}

Teaching management work is the link and bridge to ensure the steady ongoing of teaching and learning steps. All the management in universities is served for the normal work of teaching. Teaching management workers should research, explore and innovate teaching management 
methods in -depth in the actual work. However, the quality and ability of teaching management workers is not achieved overnight. It is needed for the universities to provide a good platform, and require the teaching management workers to strengthen their own learning, constantly enrich themselves, improve themselves, exercise ability and wisdom with full enthusiasm, so that the university education management is full of vitality and vitality.

\section{References:}

[1] Tian Ping'an. University Teaching Management Research [M]. Chongqing: Southwest Normal University Press, 2007.

[2] Yin Yonglin. Knowledge and Practice - Higher Education Teaching Management Exploration and Practice [M]. Kunming: Yunnan University Press, 2010.

[3] Wang Chunbo. The Innovation of Teaching Management Mode in Universities - The Decentralization of Teaching Management and the Increase of Self - management of Departments in Schools and Departments [J]. Modern Communication, 2014, (3). 